\title{
Pathogenicity, Internal Transcribed Spacer-rDNA Variation, and Human Dispersal of Ceratocystis fimbriata on the Family Araceae
}

\author{
Daniel J. Thorpe, Thomas C. Harrington, and Janice Y. Uchida
}

First and second authors: Department of Plant Pathology, Iowa State University, Ames 50011; and third author: Department of Plant and Environmental Protection Sciences, University of Hawaii, Honolulu 96822.

Accepted for publication 22 November 2004.

\begin{abstract}
Thorpe, D. J., Harrington, T. C., and Uchida, J. Y. 2005. Pathogenicity, internal transcribed spacer-rDNA variation, and human dispersal of Ceratocystis fimbriata on the family Araceae. Phytopathology 95:316323.

Ceratocystis fimbriata is a complex of many cryptic, host-specialized species that causes wilt and canker of woody species and rot diseases of storage roots and corms of many economically important plants worldwide. With the exception of the family Araceae, all confirmed hosts of C. fimbriata are dicotyledonous plants. We hypothesized that the isolates from members of the family Araceae would form a monophyletic lineage specialized to infect these unique hosts. Analyses of sequences of the internal transcribed spacer (ITS) region of nuclear rDNA indicate that isolates and herbarium specimens of $C$. fimbriata from the family Araceae represent three different groups: an Xanthosoma/Syngonium group on

Brazil; an inhame group on corms of Colocasia esculenta in Brazil; and a distantly related taro group on Colocasia esculenta in Hawaii and China and on X. sagittifolium in Fiji. Inoculations of three species of Araceae (Caladium bicolor, S. podophyllum, and Colocasia esculenta) showed that isolates from all three groups are pathogenic to these three hosts. Brazilian isolates from Mangifera indica and Ficus carica were only weakly pathogenic to Caladium and Syngonium sp. and were not pathogenic to Colocasia sp. Syngonium plants appeared to be most susceptible to isolates of the Xanthosoma/Syngonium group, and Colocasia plants were least susceptible to isolates from Syngonium spp. Thus, it appears that adaptations to the family Araceae have evolved more than once in the C. fimbriata complex. It is hypothesized that the three groups of $C$. fimbriata on the family Araceae are native to the Caribbean, Brazil, and Asia, respectively, but they have been spread elsewhere by humans.
\end{abstract} corms of Xanthosoma spp. from the Caribbean region and on ornamental S. podophyllum from greenhouses in Florida, Hawaii, Australia, and
Additional keyword: speciation.
Ceratocystis fimbriata Ellis \& Halsted is a fungal pathogen with a large and diverse host range on dicotyledonous plants. Some of the many susceptible plant species include Platanus spp., Theobroma cacao, Mangifera indica, Coffea arabica, Eucalyptus spp., Populus spp., Ficus carica, and Ipomoea batatas $(3,6,13$, $26,41)$. Symptoms include discoloration of the xylem, wilting, cankers, and rot of storage roots. More than 16 dicotyledonous families are hosts to $C$. fimbriata $(6,17)$, but only one monocotyledonous family, Araceae, contains confirmed hosts. Diseases on the family Araceae caused by C. fimbriata include basal rot of ornamental house and landscape plants in the genus Syngonium and black rot of corms of the edible aroid Colocasia esculenta (L.) Schott, which is known as taro in Asia and the Pacific, and as inhame in Brazil $(6,20,39)$. Colocasia esculenta is the most important of the aroid hosts, with worldwide production on 1.57 million ha of 9.22 million tons annually (15). We have seen similar black rot on the edible corms of Xanthosoma spp. (known as yautia, tannia, or malanga in parts of the Caribbean) and have consistently isolated $C$. fimbriata from them. The edible species of Xanthosoma are collectively known as X. sagittifolium and are grown on 34,725 ha with an annual production of 286,108 tons (15).

The earliest report of $C$. fimbriata causing disease on the family Araceae was in 1939 on Colocasia esculenta in Japan (33). Black rot disease has also been noted on the corms of Colocasia esculenta or Xanthosoma spp. in Florida, Cuba, Brazil, Fiji, and West-

Corresponding author: T. C. Harrington; E-mail address: tcharrin@ iastate.edu

DOI: 10.1094/PHYTO-95-0316

(C) 2005 The American Phytopathological Society ern Samoa (1,20,37,39). Alfieri et al. (1) reported Alocasia sp. as a susceptible host in Florida. Davis (11) found C. fimbriata causing darkened, water-soaked lesions on the pseudopetioles of the ornamental houseplant $S$. auritum in California greenhouses. The disease has been reported on other Syngonium species, including $S$. podophyllum Schott, in greenhouses in Florida, Hawaii, and Australia (1,38-40). Inoculation studies have shown that Alocasia sp., Colocasia esculenta, X. sagittifolium, Syngonium spp., and Caladium sp. are susceptible to isolates of $C$. fimbriata from the family Araceae, but Araceae isolates generally do not infect dicotyledonous hosts $(3,11,24,25,27,29,38,39)$. However, no comparisons of pathogenicity have been made among Araceae isolates.

There is substantial genetic variation within the $C$. fimbriata complex $(3,4,26,34)$, and much of this variation is associated with unique hosts or geographic regions. Three geographic clades are believed to be centered in North America, Asia, and Latin America (17). Within each geographic clade there are numerous lineages associated with certain hosts $(3,5,26)$, and inoculation studies have shown isolates of some of these lineages to be highly host specialized $(3,13,23,35)$. Although there is limited morphological variation within the complex (41), several new species have been recognized based on minor morphological variation and unique host ranges $(5,13,42)$. Many cryptic species await description using the phylogenetic species concept proposed by Harrington and Rizzo (19), in which species are recognized as monophyletic lineages with unique phenotypic characters, such as host specialization.

Because C. fimbriata is an insect-dispersed pathogen $(21,22$, 30 ), natural populations of the pathogen appear to show substantial genetic differentiation and have unique internal transcribed 
spacer (ITS) sequences $(3,14)$, and natural long-distance dispersal of populations to new continents and islands might be very rare events. However, there appears to have been movement by humans of certain host-specialized genotypes of $C$. fimbriata to new regions on propagative material and solid wood packing materials $(3,6,13,14,17)$. For instance, isolates of the sweet potato pathogen ( $C$. fimbriata sensu stricto) from China, Japan, Papua New Guinea, New Zealand, St. Vincent, and the United States show no genetic variation in ITS sequence and very limited variation in microsatellite markers $(3,13,34)$, probably because a single strain of the fungus has been moved around the world on storage roots used for propagation (13). Strains of $C$. fimbriata may also have been moved around the world on partially rotted corms of edible aroids or infected slips of ornamental aroids.

We hypothesize that there is a cryptic species in the $C$. fimbriata complex that is specifically adapted to infect the family Araceae, and this strain has been moved around the world in propagative material. This hypothesis was tested by examining the ITS sequences of isolates and herbarium specimens of $C$. fimbriata from aroids in Asia, the Pacific, the Caribbean, and Latin America and testing the pathogenicity of the isolates on three species of Araceae: Colocasia esculenta, S. podophyllum, and Caladium bicolor (Aiton) Vent.

\section{MATERIALS AND METHODS}

Fungal isolates. Most of the isolates of $C$. fimbriata were obtained from corms of Colocasia esculenta or X. sagittifolium with black rot symptoms purchased in markets and grocery stores (Table 1). Corms of these two species are similar, and in some cases the host may have been misidentified; the isolate from Cuba, in particular, may have been from either host. Isolates were also made from diseased Syngonium plants in Florida and Hawaii. Isolates were obtained by transferring ascospore masses on top of perithecia formed on the corms or by placing pieces of diseased tissue between two disks of carrot (30). Ascospore masses were transferred to malt yeast extract agar (MYEA; 2\% malt extract, $2 \%$ agar, and $0.2 \%$ yeast extract), and the pure cultures were stored at $-80^{\circ} \mathrm{C}$. Other isolates were obtained from referenced culture collections (Table 1).

Herbarium specimens from the U.S. National Fungus Collection (BPI) were also examined, and DNA was extracted from perithecia and ascospore masses of specimens on Xanthosoma, Colocasia esculenta, and Syngonium (Table 1). All of the herbarium specimens were of imported material intercepted by quarantine officials of the U.S. Department of Agriculture.

DNA extraction and ITS sequencing. Two methods were used to obtain genomic DNA from cultures for use as template in polymerase chain reactions (PCR). In one method, mycelium was grown in $25 \mathrm{ml}$ of liquid medium (2\% malt extract and $0.2 \%$ yeast extract) at room temperature for 2 weeks; DNA extraction followed the method of DeScenzo and Harrington (12). Another method used the Prepman Ultra Kit (Applied Biosystems, Foster City, CA) to extract DNA from mycelium scraped from the surface of plates of MYEA after 1 week of growth at room temperature.

Sequences of the ITS region and 5.8S gene of rDNA were obtained by PCR amplification of genomic DNA of isolates using the primers ITS1F (5'-CTTGGTCATTTAGAGGAAGTAA-3') and ITS4 (5'-TCCTCCGCTTATTGATATGC-3') following the protocol of Harrington et al. (18), with slightly different cycling conditions: initial denaturation at $94^{\circ} \mathrm{C}$ for $95 \mathrm{~s}$ followed by 35 cycles of denaturation $\left(94^{\circ} \mathrm{C}\right)$ for $35 \mathrm{~s}$, annealing at $52^{\circ} \mathrm{C}$ for $60 \mathrm{~s}$, and extension at $72^{\circ} \mathrm{C}$ for $60 \mathrm{~s}$. Final extension was at $72^{\circ} \mathrm{C}$ for

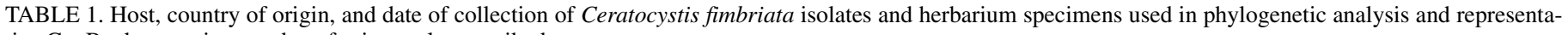
tive GenBank accession numbers for internal transcribed spacer sequences

\begin{tabular}{|c|c|c|c|c|}
\hline Isolate and specimen numbers ${ }^{\mathrm{z}}$ & GenBank accession no. & Host plant & Location & $\begin{array}{l}\text { Years of } \\
\text { collection }\end{array}$ \\
\hline \multicolumn{4}{|l|}{ C1859-1861, C1863-1864, 1865 (= CBS 114713), } & 2001-2002 \\
\hline C1875-1876, C1904, 1905 (= CBS 115171), C1907, & & & & \\
\hline C1914-1918, C1920-1922, C1925-1926, C1929 & AY526288 & Colocasia esculenta & São Paulo State, Brazil & 2002 \\
\hline C1900 (= CBS 115170), C1902-1903, C1911-1912 & AY526287 & Colocasia esculenta & Distrito Federal, Brazil & 2002 \\
\hline C2005-2006, C2008-2009 & AY526290 & Colocasia esculenta & Bahia, Brazil & 2002 \\
\hline C2030, C2032 & AY526289 & Colocasia esculenta & Rondônia, Brazil & 2003 \\
\hline \multicolumn{5}{|l|}{ C1714 (= CBS 115164, BPI 843732), C1715 } \\
\hline$(=$ CBS 114720, BPI 843733$)$ & AY526306, AY526307 & Colocasia esculenta & Hawaii, USA & 1991, 1998 \\
\hline BPI 596161, BPI 596162 & AY526304, AY526305 & Colocasia esculenta & Imported from China & 1949 \\
\hline C1817 (= CBS 114718) & AY526298 & $\begin{array}{l}\text { Xanthosoma sp. } \\
\quad \text { or Colocasia esculenta }\end{array}$ & Cuba & 2001 \\
\hline C1641 & AY 157963 & Xanthosoma sp. & Costa Rica & 2000 \\
\hline $\mathrm{C} 1780$ (= CBS 115165) & AY526297 & $X$. sagittifolium & Costa Rica & 2001 \\
\hline C2043-2048 & AY526296 & Xanthosoma sp. & Puerto Rico & 2003 \\
\hline BPI 595881, BPI 596216, BPI 596217, BPI 596222 & $\begin{array}{l}\text { AY526301, AY526300, } \\
\text { AY526303, AY526302 }\end{array}$ & Xanthosoma sp. & Dominican Republic & $\begin{array}{r}1935,1963, \\
1963,1970\end{array}$ \\
\hline BPI 595396 & AY526299 & X. bataviense & Cuba & 1930 \\
\hline C1931 (= DAR 58902; BPI 843739) & AY526308 & $X$. sagittifolium & Fiji & Unknown \\
\hline BPI 595880 & AY526293 & Syngonium sp. & Brazil & 1985 \\
\hline C1717 (= CBS 114719) & AY526294 & Syngonium sp. & Hawaii, USA & Unknown \\
\hline C2119 (= DAR 59740a) & & Syngonium sp. & Australia & 1987 \\
\hline $\mathrm{C} 1774, \mathrm{C} 1781, \mathrm{C} 1809$ (= CBS 115167) & AY526295 & S. podophyllum & Florida, USA & 2001 \\
\hline C1558 (= CBS 115175) & AY157965 & Mangifera indica & Rio de Janeiro State, Brazil & 1999 \\
\hline C1688 (= CBS 114721) & AY526291 & M. indica & São Paulo State, Brazil & 2000 \\
\hline C1782 (= CBS 115166) & AY526292 & Ficus carica & São Paulo State, Brazil & 2001 \\
\hline C925 (= CBS 115173) & AY157967 & Gmelina arborea & Pará, Brazil & 1996 \\
\hline C1345 & AY157966 & Eucalyptus sp. & Bahia, Brazil & 1998 \\
\hline C996 (= C948, CBS 146.53, ATCC 14503) & AY157959 & Coffea arabica & Suriname & 1953 \\
\hline C1317 (= CBS 115162) & AY157958 & Platanus occidentalis & North Carolina, USA & 1998 \\
\hline C1548 (= CBS 114722, BPI 843730) & AY157952 & Theobroma cacao & Costa Rica & 1999 \\
\hline
\end{tabular}

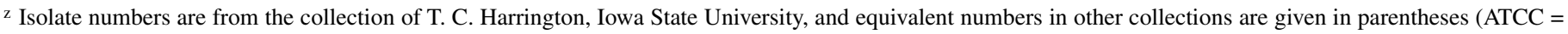

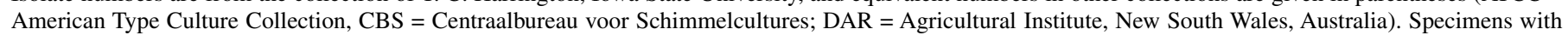
BPI numbers are in the U.S. National Fungus Collections. 
15 min. Complementary sequences of the PCR product were obtained with the same primers at the Iowa State University DNA Sequencing and Synthesis Facility.

Template DNA was extracted from herbarium specimens using mycelium or three to four perithecia with ascospores and the Prepman Ultra Kit (Applied Biosystems). Because these specimens frequently included mold spores, primers specific to $C$. fimbriata $\left(\right.$ Cerat $1 \mathrm{~F}=5^{\prime}$-GCGGAGGGATCATTACTGAG-3' ${ }^{\prime}$ and 1CFL-R = 5'-TGATCCGAGGTCAACCTTGTG-3') were designed and used to amplify the ITS region in $100-\mu$ reactions. Cycling conditions were the same as described previously. The PCR products from three to four reactions of each specimen were concentrated and combined using MicroCon filters (Millipore, Billerica, MA). The products were run on a $2 \%$ agarose gel, and bands of the appropriate size $(600 \mathrm{~kb})$ were cut out, purified with a Gene Clean Kit (Qbiogene, Carlsbad, CA), and inserted into PGEMT-Easy Vector (Promega, Madison, WI). Transformed plasmids were inserted into competent cells, clones were grown, and plasmids were purified using the Qiagen Kit (Valencia, CA). Sizes of the insertions were checked after restriction with EcoRI (Invitrogen, Carlsbad, CA), and those of the correct size were sequenced using primers of the vector sequence.

Phylogenetic analysis. In addition to the sequences of isolates and herbarium specimens from the family Araceae, representative sequences of isolates of $C$. fimbriata from the Latin American clade (3) were used in the analyses. Among more than 280 ITS sequences currently available, we selected sequences most similar to those of Araceae isolates. Isolates from Hawaii and Fiji and dried specimens from China had unique ITS sequences that matched most closely those of the recently described species $C$. pirilliformis (5), and these sequences (accession nos. AF427104, AF427105, and AF427106) were added to the data set. C. albofundus isolate C1048 from Acacia mearnsii in South Africa was used as the outgroup taxon. There were 75 ITS sequences in the data set. Sequences were aligned manually by adding gaps, and the data set was analyzed with phylogenetic analysis using parsimony (PAUP) version 4.0b10 (35).

As has been found earlier in ITS analyses of the $C$. fimbriata complex (3), there were numerous large insertion-deletions (indel) in the aligned data set, and these indel regions could not be unambiguously aligned. Of the 712 total characters in the ITS/5.8S data set, including gaps, 215 were ambiguously aligned and excluded from the analysis, 97 remaining sites were variable, and of these, 59 were parsimony-informative. After deletion of ambiguously aligned characters, all gaps were only a single base pair (bp). Thus, gaps were treated as a fifth character without fear of biasing the data analysis. A maximum parsimony heuristic search was performed with all characters having equal weight. Stepwise addition was used to obtain starting trees, and treebisection-reconnection was used. Bootstrap analysis with 1,000 replications of heuristic searches was used to assess support for the internal branches.

Pathogenicity tests. Host plants. Representative isolates of the C. fimbriata lineages from the family Araceae (identified by ITS sequences) were inoculated into Caladium bicolor cv. Pink Beauty, S. podophyllum (believed to be cv. White Butterfly), and Colocasia esculenta. Brazilian isolates of $C$. fimbriata from the dicot hosts $M$. indica (mango) and $F$. carica (edible fig) were also inoculated into the three hosts.

The Caladium bicolor plants were grown from bulbs that were purchased from Caladium Bulb Company (Lakeland, FL), and the Colocasia esculenta plants were grown from corms that were purchased from various grocery stores in Ames and Des Moines, IA. The bulbs and corms were placed directly into 4- to 6-in. pots, and the plants were allowed to grow for 3 to 4 months and 1 to 2 months, respectively, before inoculation. The $S$. podophyllum plants were vegetatively propagated from a single houseplant, placed into 4-in. pots, and grown for 7 months before inoculation.
All plants were grown in pasteurized potting mix (25\% peat, $25 \%$ soil, and $50 \%$ perlite) in a greenhouse in full sun, with a maximum daily temperature of approximately $25^{\circ} \mathrm{C}$. The plants were adequately watered and fertilized (25\% Peter's Excel 21-5-20, 75\% Peter's Cal-Mag Special 15-5-15) weekly.

Inoculations. Seven days prior to inoculation, plants were placed in a growth chamber set at $25^{\circ} \mathrm{C}$ with a $16 / 8 \mathrm{~h}$ light/dark cycle with illumination of approximately $95 \mu \mathrm{mol} \mathrm{cm} \mathrm{cm}^{-2} \mathrm{~s}^{-1}$ of photosynthetically active radiation. Plants were well-watered in the growth chamber prior to and during inoculation experiments.

Self-fertile, single-ascospore progeny of each isolate were transferred onto MYEA and grown at room temperature for 7 days. Inoculum was prepared by flooding each culture with $10 \mathrm{ml}$ of sterile deionized water (SDW), scraping the mycelium with a sterile spatula, and filtering the suspension through four layers of sterile cheesecloth, which was rinsed with an additional $5 \mathrm{ml}$ of SDW. Spore concentration was estimated with a hemacytometer, diluted to $2.0 \times 10^{5}$ spores per $\mathrm{ml}$, and loaded into sterile syringes (needle gauge 21). Spore suspensions consisted almost entirely of cylindrical endoconidia, although there were some ascospores and hyphal fragments. Controls were prepared following the same technique using a sterile MYEA plate.

For each of the three host species, pseudopetioles of the youngest, fully expanded leaf were wounded by punching a hole through the pseudopetiole about $3 \mathrm{~cm}$ above the soil line with the syringe, and approximately $0.2 \mathrm{ml}$ of spore suspension was injected. The inoculation site was wrapped with Parafilm. The inoculated leaves were monitored daily for death or wilting. After 25 to 31 days, each pseudopetiole was sliced open vertically above and below the point of inoculation, and the length of xylem discoloration was measured. To reisolate the fungus, discolored tissue was placed between two carrot disks and incubated under humid conditions at room temperature. After 7 to 14 days, the carrot disks were observed for growth of $C$. fimbriata.

Statistical analyses. Two experiments with each host were performed with four replications (for the Caladium experiments, the first Colocasia experiment, and the control treatment in the second experiment) or five replications of each treatment in a completely randomized design. Only one host was in the growth chamber in each experiment. Data on the length of xylem discoloration and days until death (dead pseudopetioles per leaves) were analyzed using a multifactorial analysis of variance (ANOVA) including isolate, source (host) of inoculum, and experiment. Data from the two experiments on each host were combined if there was homogeneity of variances, otherwise the data from the two experiments were analyzed separately. When ANOVA indicated significant variation among isolates $(P \leq 0.05)$, Fisher's protected least significant difference test was used to make pairwise mean comparisons among the treatments. Percent mortality and reisolation success were compared between each isolate and the control using Fisher's exact test adjusted for multiple comparisons by the Bonferroni method. All statistics were performed using SAS statistical software (SAS Institute, Cary, NC).

\section{RESULTS}

ITS sequence analysis. There was substantial variation in ITS sequences among the isolates and herbarium specimens from the family Araceae. There were six ITS sequences (genotypes) identified among the 49 Brazilian isolates from Colocasia found in markets, distribution centers, and grocery stores in four states and the Distrito Federal. Three of these genotypes were found in São Paulo, the main production area for inhame in Brazil and where most of the diseased corms are believed to have been infected (20). The Syngonium isolates from Florida, Hawaii, and Australia had an ITS/5.8S sequence of $528 \mathrm{bp}$ that was identical to that of the Syngonium specimen from Brazil. The nine Xanthosoma 
isolates from Costa Rica, Cuba, and Puerto Rico had identical ITS/5.8S sequences of $527 \mathrm{bp}$, and this sequence was identical to that of the five herbarium samples from Xanthosoma collected in Cuba and the Dominican Republic. Colocasia esculenta isolates from Hawaii, Colocasia esculenta specimens from China, and the Xanthosoma isolate from Fiji had a distinct ITS/5.8S sequence of 565 bp that differed greatly from other isolates of $C$. fimbriata.

Two most-parsimonious trees of 133 steps were derived from the 59 parsimony-informative characters from the total aligned data set. As seen in Figure 1, the ITS sequences of Colocasia isolates from Brazil were found among the sequences of various South American isolates from dicot hosts representing the Latin American clade of the $C$. fimbriata complex $(3,17)$. Included in this moderately supported clade (bootstrap value $=86$ ) of South American isolates was a North Carolina isolate of the Platanus pathogen, recently recognized as $C$. platani, and the $T$. cacao pathogen $C$. cacaofunesta (13). Sister to the South American group of isolates were isolates from Xanthosoma and Syngonium.

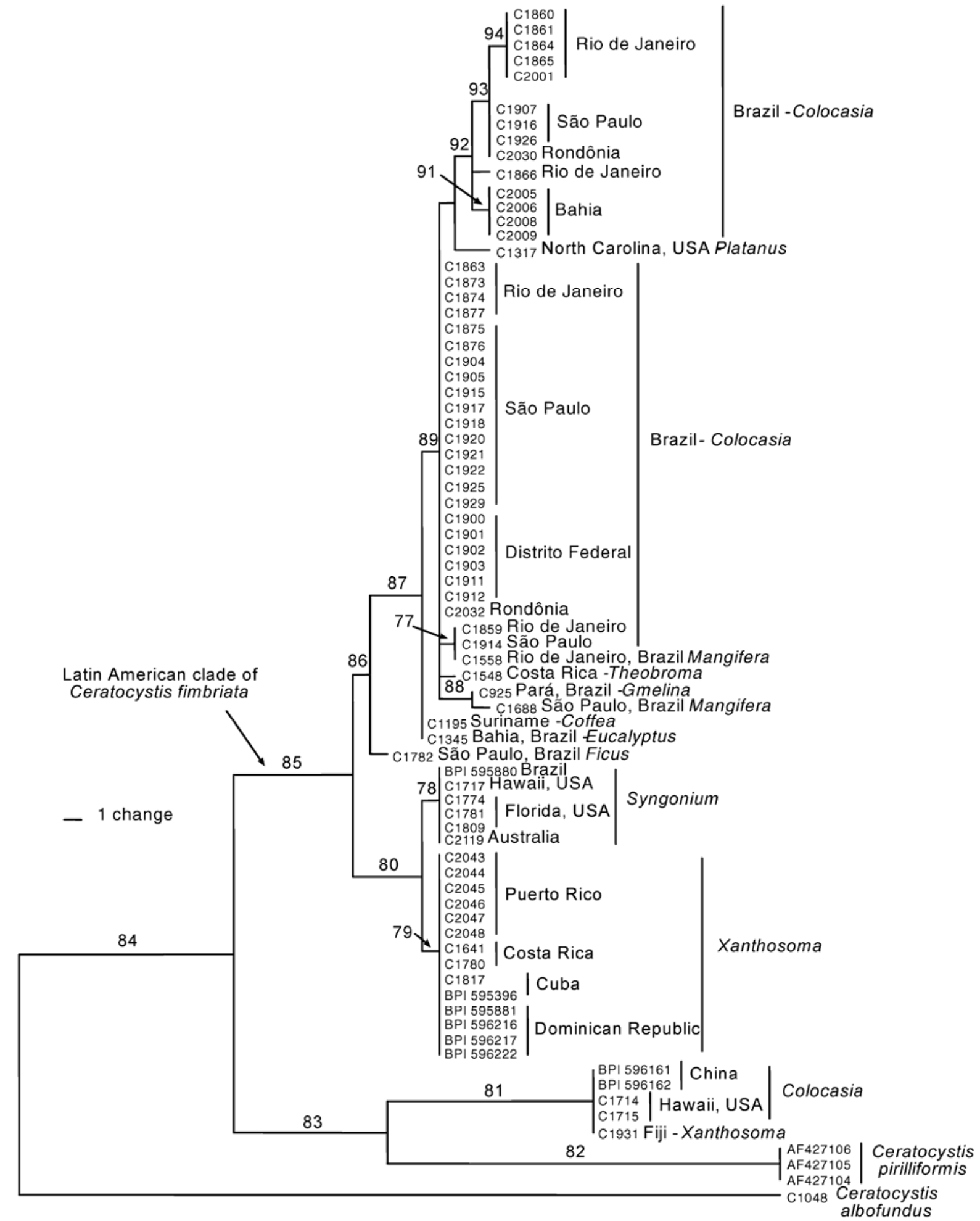

Fig. 1. One of two most-parsimonious trees of 133 steps using rDNA-internal transcribed spacer sequences of Ceratocystis fimbriata isolates and herbarium specimens and C. pirilliformis. C. albofundus was used as the outgroup taxon. The consistency index, retention index, and rescaled consistency index were 0.827 , 0.952, and 0.787, respectively. Bootstrap values greater than 50 are shown above the branch. 
The sequences of the Syngonium and Xanthosoma genotypes differed by only $2 \mathrm{bp}$, and these genotypes grouped together in a clade with a moderate bootstrap support of 80 . The ITS sequence of the Asian and Pacific isolates and specimens from Colocasia and Xanthosoma was most similar to that of $C$. pirilliformis (Fig. 1). In the second most-parsimonious tree, BPI 596162 differed from the other Asian Colocasia isolates by a single base substitution.

Pathogenicity tests. Caladium bicolor. In both experiments there was substantial, natural senescence of both inoculated and control pseudopetioles of Caladium during the course of the experiments. Half of the pseudopetioles inoculated with the water control died (Table 2). Counting dead pseudopetioles only, days to mortality in the two experiments varied significantly by isolate $(F=3.35 ; P=0.0011)$ and experiment $(F=5.79 ; P=0.019)$, and there was significant isolate-experiment interaction $(F=2.67$; $P=0.007)$. There was no difference in the time (in days) to mortality (of the pseudopetiole and leaf) between the inoculated and the control plants in the first experiment, but in the second experiment, pseudopetioles inoculated with all $C$. fimbriata isolates except the Mangifera isolate died sooner than those inoculated with water only.

There was homogeneity of the variances in the two experiments for length of xylem discoloration, and the means shown in Table 2 are for the combined data of the two experiments. All isolates from the family Araceae caused more xylem discoloration than the controls, but the Mangifera and Ficus isolates caused no more discoloration than the controls (Table 2). With all the isolates, the pathogen was reisolated from most of the inoculated plants, but the fungus was not recovered from the control plants.

S. podophyllum. The two isolates from Syngonium and the related Xanthosoma isolates from Costa Rica and Cuba killed all inoculated pseudopetioles of Syngonium (Table 2). Two of the control pseudopetioles also died, and one of the Colocasia isolates from Hawaii killed $90 \%$ of the inoculated pseudopetioles. Only the pseudopetioles inoculated with the Syngonium and Xanthosoma isolates and Colocasia isolate C1900 died sooner than the control pseudopetioles.

The ANOVA indicated that there was significant variation in the length of xylem discoloration among the isolates inoculated into the Syngonium plants $(F=8.90 ; P<0.0001)$. All isolates except C1865 from Colocasia in Brazil and the Mangifera isolate caused more xylem discoloration than the controls. The Syngonium and Xanthosoma isolates caused significantly more discoloration in the pseudopetioles of Syngonium than all other isolates and the control, except for the Ficus isolate. The fungus was reisolated from $100 \%$ of the plants inoculated with isolates C1809, C1780, and $\mathrm{C} 1688$.

Colocasia esculenta. Two of eight control pseudopetioles died, and $C$. fimbriata was recovered from each of these pseudopetioles, though there was little discoloration in the xylem of either plant. Thus, there was cross-contamination, but $C$. fimbriata may have colonized the pseudopetiole of the control plants after the pseudopetiole died. All Araceae isolates, except C1717, caused $100 \%$ mortality of inoculated pseudopetioles of Colocasia, significantly greater than that of the Ficus and Mangifera isolates and the controls (Table 2). Days until death and percent reisolation from Colocasia ( $100 \%$ for all isolates) did not differ among treatments.

Xylem discoloration in inoculated Colocasia plants varied significantly by isolate $(F=7.34 ; P<0.0001)$, experiment $(F=$ 46.29; $P<0.0001)$, and isolate-experiment interaction $(F=2.5$; $P=0.009)$. The variances of the two experiments were not homogeneous, so the two experiments were analyzed separately. In the first experiment, the three Brazilian isolates from Colocasia, one Hawaiian isolate from Colocasia, and one Xanthosoma isolate caused more discoloration than the controls. In the second experiment, all isolates from the corms of Colocasia or Xanthosoma caused xylem discoloration greater than that found in the control inoculations, but isolates from Syngonium, Mangifera, and Ficus caused no more discoloration than the controls.

\section{DISCUSSION}

Analysis of ITS sequences from isolates and herbarium specimens up to 70 years old suggest that $C$. fimbriata genotypes from the family Araceae represent several cryptic species that have been moved around the world by humans. All isolates and specimens from Xanthosoma species in the Caribbean region had the identical ITS sequence (the Xanthosoma genotype), the Syngonium isolates and specimen had an identical ITS sequence (the Syngonium genotype) that differed by only $2 \mathrm{bp}$ from the Xanthosoma genotype, and the Colocasia specimens from China had the same ITS sequence (the taro genotype) as Hawaiian

TABLE 2. Percent mortality, days from inoculation to death of pseudopetiole, and average length of xylem discoloration in family Araceae plants inoculated with isolates of Ceratocystis fimbriata

\begin{tabular}{|c|c|c|c|c|c|c|c|c|c|c|c|c|c|}
\hline \multirow{3}{*}{$\begin{array}{l}\text { Source } \\
\text { of isolate }\end{array}$} & \multirow[b]{3}{*}{ Location } & \multirow{3}{*}{$\begin{array}{l}\text { Isolate } \\
\text { number }\end{array}$} & \multicolumn{4}{|c|}{ Caladium bicolor } & \multicolumn{3}{|c|}{ Syngonium podophyllum } & \multicolumn{4}{|c|}{ Colocasia esculenta } \\
\hline & & & \multirow{2}{*}{$\begin{array}{c}\% \\
\text { Mor- } \\
\text { tality }\end{array}$} & \multicolumn{2}{|c|}{ Days to death ${ }^{\mathrm{xy}}$} & \multirow{2}{*}{$\begin{array}{c}\text { Xylem } \\
\text { discoloration } \\
(\mathrm{cm})^{\mathrm{z}}\end{array}$} & \multirow{2}{*}{$\begin{array}{c}\% \\
\text { Mor- } \\
\text { tality }\end{array}$} & \multirow{2}{*}{$\begin{array}{l}\text { Days } \\
\text { to } \\
\text { death }\end{array}$} & \multirow{2}{*}{$\begin{array}{c}\text { Xylem } \\
\text { discoloration } \\
(\mathrm{cm})^{\mathrm{z}}\end{array}$} & \multirow{2}{*}{$\begin{array}{c}\% \\
\text { Mor- } \\
\text { tality }\end{array}$} & \multirow{2}{*}{$\begin{array}{c}\text { Days } \\
\text { to } \\
\text { death }\end{array}$} & \multicolumn{2}{|c|}{$\begin{array}{l}\text { Xylem discol- } \\
\text { oration }(\mathrm{cm})^{\mathrm{y}}\end{array}$} \\
\hline & & & & Exp. $1^{z}$ & Exp. $2^{z}$ & & & & & & & Exp. $1^{z}$ & Exp. $2^{z}$ \\
\hline \multirow{2}{*}{ Syngonium } & Hawaii & C1717 & 100 & 8.8 & $7.5 \mathrm{ab}$ & $1.8 \mathrm{a}$ & $100^{* * *}$ & $16.6 \mathrm{ab}$ & $3.4 \mathrm{a}$ & 55.6 & $21.6 \mathrm{c}$ & $1.7 \mathrm{cde}$ & $1.6 \mathrm{c}$ \\
\hline & Floric & C1809 & 100 & 10.0 & $8.0 \mathrm{ab}$ & $1.5 \mathrm{a}$ & $100 * *$ & $16.2 \mathrm{ab}$ & $3.1 \mathrm{a}$ & $100^{*}$ & $19.1 \mathrm{c}$ & $2.3 \mathrm{bcd}$ & $3.5 \mathrm{bc}$ \\
\hline \multirow[t]{2}{*}{ Xanthosoma } & Costa Rica & C1780 & 100 & 10.0 & $7.5 \mathrm{ab}$ & $1.8 \mathrm{a}$ & $100 * *$ & $15.0 \mathrm{a}$ & $3.3 \mathrm{a}$ & $100 *$ & $13.8 \mathrm{ab}$ & $2.5 b c$ & $9.3 \mathrm{a}$ \\
\hline & Cuba & C1817 & 100 & 9.3 & $9.0 \mathrm{ab}$ & $1.9 \mathrm{a}$ & $100 * *$ & $15.0 \mathrm{a}$ & $3.0 \mathrm{ab}$ & $100^{*}$ & $12.3 \mathrm{ab}$ & $2.0 \mathrm{cde}$ & $6.1 \mathrm{ab}$ \\
\hline \multirow{3}{*}{ Colocasia } & & $\mathrm{C} 1 \mathrm{~s}$ & 100 & 9.8 & $9.3 \mathrm{ab}$ & $1.4 \mathrm{a}$ & 50 & $19.8 \mathrm{bcd}$ & $2.1 \mathrm{~cd}$ & $100 *$ & $12.9 \mathrm{ab}$ & $3.6 \mathrm{ab}$ & $7.3 \mathrm{a}$ \\
\hline & Hawaii & C1714 & 100 & 10.0 & $6.5 \mathrm{a}$ & 1.6 & 90 & $19.8 \mathrm{~cd}$ & $2.1 \mathrm{~cd}$ & $100 *$ & $10.0 \mathrm{a}$ & $2.3 \mathrm{bcd}$ & $7.0 \mathrm{ab}$ \\
\hline & & $\mathrm{C} 1715$ & 100 & 10.0 & $8.0 \mathrm{ab}$ & $1.3 \mathrm{a}$ & 20 & $22.5 \mathrm{~cd}$ & $1.8 \mathrm{cde}$ & $100^{*}$ & $11.2 \mathrm{ab}$ & $2.4 \mathrm{bc}$ & $7.4 \mathrm{a}$ \\
\hline Mangifera & Brazil & C1688 & 75 & 14.5 & $9.8 \mathrm{bc}$ & $0.5 \mathrm{c}$ & 10 & $22.0 \mathrm{~cd}$ & $1.5 \mathrm{def}$ & 22.2 & $25.0 \mathrm{~cd}$ & $0.7 \mathrm{e}$ & $2.0 \mathrm{c}$ \\
\hline Ficus & Brazil & C1782 & 75 & 15.3 & $6.0 \mathrm{a}$ & $0.6 \mathrm{bc}$ & 10 & $17.0 \mathrm{abcd}$ & $2.3 \mathrm{bc}$ & 22.2 & $29.5 \mathrm{~d}$ & $1.1 \mathrm{cde}$ & $1.4 \mathrm{c}$ \\
\hline Control & & & 50 & 12.0 & $25.0 \mathrm{c}$ & $0.3 \mathrm{c}$ & 20 & $25.0 \mathrm{~d}$ & $0.7 \mathrm{f}$ & 25.0 & $18.0 \mathrm{bc}$ & $0.8 \mathrm{de}$ & $0.5 \mathrm{c}$ \\
\hline
\end{tabular}

${ }^{\mathrm{w}}$ Values of percent mortality (of pseudopetioles) within a column followed by one or two asterisks are significantly different $(P<0.05$ and 0.01 , respectively) from the control according to Fisher's exact test (Bonferroni adjusted $\alpha=0.0045$ and 0.00091 , respectively). No isolate caused significantly more mortality than the control in the Caladium experiment.

${ }^{x}$ Days to death include only those plants that died before the end of the experiment, which was 25 days for the Caladium experiments, 28 days for the Syngonium experiments, 31 days for the first Colocasia experiment, and 28 days for the second Colocasia experiment.

y There was no homogeneity of variances for the first and second experiments, so the data for the two experiments were analyzed separately.

${ }^{\mathrm{z}}$ Numbers within a column followed by the same letter are not significantly different $(P<0.05)$ based on Fisher's protected least significant difference. Analysis of variance indicated that there was no significant variation among the isolates in the days until death in the first Caladium experiment. 
Colocasia isolates and the Xanthosoma isolate from Fiji. In contrast, there was some limited variability in ITS sequences of Colocasia isolates from Brazil (the inhame genotypes).

Isolates from the family Araceae appear to be uniquely pathogenic to aroids. In our pathogenicity tests, the Mangifera and Ficus isolates, in contrast to Araceae isolates, caused no more xylem discoloration than the controls in inoculated Caladium or Colocasia pseudopetioles, and there was only slight discoloration in Syngonium plants inoculated with the Ficus isolate. Baker et al. (3) found that isolates from M. indica, Eucalyptus sp., T. cacao, I. batatas, Platanus occidentalis, Coffea arabica, and G. arborea from the United States and Latin America were not pathogenic to Colocasia esculenta, and Costa Rican isolates from Coffea arabica and T. cacao were not pathogenic to X. sagittifolium. In contrast, our Xanthosoma isolate from Costa Rica was not pathogenic to I. batatas, Platanus occidentalis, Coffea arabica, or T. cacao (3). A C. fimbriata isolate from Syngonium in Australia failed to infect I. batatas, Platanus orientalis, or Prunus spp. but was pathogenic to various cultivars of Syngonium sp., Caladium sp., Alocasia sp., and X. lindenii (39). Japanese isolates from I. batatas were pathogenic to I. batatas plants but not to Colocasia esculenta, and the reverse was true for Japanese Colocasia esculenta isolates $(24,25,27,29)$.

There was no significant difference among Araceae isolates in days until death or the length of xylem discoloration in Caladium sp., which had been shown to be susceptible to a Syngonium isolate of $C$. fimbriata in an earlier study (39). However, natural infection of this common ornamental plant has not been reported. We found that Syngonium plants were most severely affected by the two Syngonium isolates and the related Xanthosoma isolates from Cuba and Costa Rica. The two Syngonium isolates appeared to be less aggressive than the other Araceae isolates on Colocasia esculenta. However, the Syngonium isolate from Hawaii that was not pathogenic to Colocasia esculenta is very old, and it was earlier shown to be pathogenic to this host (38). Our Costa Rican isolate from Xanthosoma was pathogenic to X. sagittifolium and Colocasia esculenta, and $X$. sagittifolium appeared to be more susceptible than Colocasia esculenta (3).

Much of the ITS sequence data had to be eliminated from analysis because of ambiguous alignment (3), and there are other limitations for using rDNA sequences for inferring evolutionary history (2). Nonetheless, ITS analyses, incompatibility testing, and pathogenicity tests suggest that the isolates and specimens from the family Araceae represent at least three cryptic species in the C. fimbriata complex. Colocasia specimens from China, the Colocasia isolates from Hawaii, and the Xanthosoma isolate from Fiji had the identical ITS sequence, which was distinct from the sequences of other aroid isolates. Analyses of isozyme electromorphs and MAT-2 sequences place this taro genotype in the Asian clade of the $C$. fimbriata complex $(17,23,32)$, and our ITS sequence analysis groups the taro pathogen with the recently described species $C$. pirilliformis, which was collected from wounds on Eucalyptus nitens in Australia (5). The taro pathogen also has minor morphological characters that distinguish it from $C$. fimbriata sensu stricto, the Ipomoea pathogen, which is in the Latin American clade $(13,32)$.

The other aroid isolates and specimens fell into the Latin American clade based on ITS analysis $(2,17)$. Xanthosoma isolates from the Caribbean region and the Syngonium specimen and isolates formed a moderately supported subclade that was sister to the rest of the Latin American clade, including isolates from dicots and Brazilian isolates from Colocasia. Our ongoing multiple gene phylogenies (unpublished data) also separate the Caribbean Xanthosoma/Syngonium isolates from Brazilian Colocasia isolates and other South American isolates. Isolates of the Xanthosoma/Syngonium subclade are sexually compatible with each other but not with Brazilian Colocasia isolates in interfertility tests (unpublished data). The Colocasia isolates from
Brazil had ITS sequences similar to each other, but they did not form a monophyletic group. The related Ficus and Mangifera isolates from Brazil were weakly pathogenic to Colocasia in the current study. Brazilian isolates from $M$. indica, $F$. carica, Eucalyptus spp., and G. arborea were at least weakly pathogenic to Colocasia esculenta in other inoculation experiments and were interfertile with Brazilian Colocasia isolates in laboratory pairings (36). More work will be done on the host range and relatedness of Brazilian isolates of $C$. fimbriata, but sexual compatibility and variability in ITS sequences and aggressiveness to various exotic hosts suggest that the Brazilian isolates are representatives of single species native to Brazil (36).

It has been hypothesized that natural populations of $C$. fimbriata tend to have restricted geographic ranges, populations vary in their aggressiveness to various hosts, and some isolated populations of $C$. fimbriata have become specialized to native hosts (3). Host specialization may be facilitated by propagation and cultivation of certain hosts, which may select for genotypes of C. fimbriata that are particularly aggressive to that host. Natural populations of $C$. fimbriata tend to be geographically restricted and have limited genetic variation $(3,13,14,17)$ because the fungus is insect dispersed and not wind dispersed (21,22,31). The primary insect vectors (Nitidulidae: Coleoptera) are fungal feeding insects that are not associated with particular plants. Successful establishment of a host-specialized strain of C. fimbriata on a new island or continent would require that the fungus survive as spores on the insect during the flight, and the insect would then have to visit a fresh wound on a susceptible host, an extremely unlikely event. In contrast, host-specialized strains of $C$. fimbriata are easily dispersed by humans on diseased propagative material or in wood $(3,13,14,17)$.

Dispersal of Araceae strains of $C$. fimbriata by humans is likely to have occurred on cuttings or corms. The edible aroids are typically propagated from corms, and the rot caused by $C$. fimbriata is often superficial and generally does not destroy the entire corm. More isolates of the Asian taro pathogen are needed, but it could be speculated that the taro ITS genotype had a limited geographic range before human cultivation of its host, which is believed to be native to eastern or southern Asia and has been cultivated in southern China for millennia $(7,9)$. Colocasia esculenta was widely dispersed by humans throughout the Pacific before European exploration (28), and the taro genotype of $C$. fimbriata could have been carried on black-rotted corms to Fiji, the Samoan Islands, and Hawaii. The Hawaiian Islands are particularly remote and did not have taro until colonization by Polynesians. One of our taro isolates (C1715) was from a long-abandoned paddy of an ancient, noncommercial cultivar of taro that was used by native Hawaiians. This paddy was in a roadless area in the Nualolokai Valley on the island of Kauai, far from known cultivation of taro in recent times.

The species of Xanthosoma that are cultivated for their edible corms and foliage may have originated from northern South America and were carried to various Caribbean Islands and Central America by Amerindians before the arrival of Columbus $(8,16)$. Identical ITS sequences were found for the Xanthosoma isolates from Costa Rica, Cuba, and Puerto Rico and for the herbarium specimens from Cuba and the Dominican Republic, suggesting that the Caribbean population on cultivated Xanthosoma plants has gone through a genetic bottleneck. We have twice collected the Xanthosoma genotype of $C$. fimbriata from corms in small markets in the northern (Caribbean) region of Costa Rica, where Amerindians were cultivating Xanthosoma before the arrival of Europeans (16).

The Syngonium isolates may represent a single genotype of the Xanthosoma/Syngonium pathogen that has been dispersed on vegetatively propagated Syngonium plants. It was earlier suggested $(39,40)$ that the Syngonium pathogen was introduced to Australia on vegetatively propagated material, and the Australian 
isolate we studied had the same ITS sequence as Syngonium isolates from Florida and Hawaii and the specimen from Brazil. Some of the commonly used cultivars of Syngonium are native to the Caribbean and Central America (10), and the Syngonium genotype of $C$. fimbriata may have originated from a naturally infected wild plant used for cultivation.

Ribosomal DNA sequences proved highly valuable in identifying genotypes of $C$. fimbriata. There are limitations in using rDNA sequences for phylogenetic analyses, and rDNA gene trees do not always reflect species trees (2), but rDNA sequences are easily generated because of the universal PCR primers for amplifying these regions and the high copy number of nearly identical tandem repeats. This high copy number allows for the amplification of rDNA regions from poor quality template DNA, such as that extracted from small quantities of herbarium material more than 70 years old. Taxa-specific primers were needed to preferentially amplify from the genomic DNA of the target organism versus the genomic DNA of molds, mycoparasites, and other eukaryotic organisms. With many of our herbarium samples, PCR had to be attempted several times, PCR products from several reactions had to be combined, and cloning of the PCR fragments was necessary to obtain quality DNA sequences. The fidelity of those sequences was evident in that the sequences generated from herbarium specimens collected from Xanthosoma, Syngonium, and Colocasia isolates matched precisely the sequences of isolates from these respective hosts. Herbarium specimens appear to be an underutilized resource in the phylogenetics, species delimitation, and historical tracking of genotypes of fungal plant pathogens.

The monocotyledonous genera Colocasia, Syngonium, Xanthosoma, and Alocasia are unique among the 28 genera known to be susceptible to $C$. fimbriata (6), and isolates of $C$. fimbriata from dicotyledonous hosts are not strongly pathogenic to the family Araceae. We speculate that at least three host-specialized populations of $C$. fimbriata from Asia and the Caribbean region have been moved by humans to new continents and islands on infected corms of Colocasia and Xanthosoma plants and in vegetatively propagated Syngonium plants. We are conducting further studies with Brazilian populations of $C$. fimbriata on Colocasia esculenta (20) and other hosts, but the inhame pathogen appears to be indigenous to Brazil, perhaps to the São Paulo region, and it may not be restricted to the family Araceae (36).

\section{ACKNOWLEDGMENTS}

This research was supported by the National Science Foundation through grants DEB-987065 and DEB-0128104. We thank C. J. B. Engelbrecht and J. Steimel for generating some of the DNA sequences; T. Hurt (University of Florida) and M. Priest (Agricultural Institute, New South Wales, Australia) for assistance in obtaining isolates; and the U.S. National Fungus Collection for providing access to herbarium specimens and cooperation.

\section{LITERATURE CITED}

1. Alfieri, S. A., Langdon, K. R., Kimbrough, J. W., El-Gholl, N. E., and Wehlburg, C. 1994. Diseases and disorders of plants in Florida. Fla. Dep. Agric. Conserv. Serv. Bull. 14.

2. Álvarez, I., and Wendel, J. F. 2003. Ribosomal ITS sequences and plant phylogenetic inference. Mol. Phylogen. Evol. 29:417-434.

3. Baker, C. J., Harrington, T. C., Krauss, U., and Alfenas, A. C. 2003. Genetic variability and host specialization in the Latin American clade of Ceratocystis fimbriata. Phytopathology 93:1274-1284.

4. Barnes, I., Gaur, A., Burgess, T., Roux, J., Wingfield, B. D., and Wingfield, M. J. 2001. Microsatellite markers reflect intra-specific relationships between isolates of the vascular wilt pathogen Ceratocystis fimbriata. Mol. Plant Pathol. 2:319-325.

5. Barnes, I., Roux, J., Wingfield, B. D., Dudzinski, M. J., Old, K. M., and Wingfield, M. J. 2003. Ceratocystis pirilliformis, a new species from Eucalyptus nitens in Australia. Mycologia 95:865-871.

6. $\mathrm{CAB}$ International. 2001. Ceratocystis fimbriata (original text prepared by C. J. Baker and T. C. Harrington). In: Crop Protection Compendium. CAB International, Wallingford, UK.
7. Cable, W. J. 1984. The spread of taro (Colocasia sp.) in the Pacific. In: Edible Aroids. S. Chandra, ed. Clarendon Press, Oxford.

8. Clement, C. R. 1994. Crops of the Amazon and Orinoco regions: Their origin, decline and future. Pages 195-203 in: Neglected Crops: 1492 from a Different Perspective. J. E. Hernández-Bermejo and J. León, eds. FAO Plant Production and Protection Series, Rome.

9. Coates, D. J., Yen, D. E., and Gaffey, P. M. 1988. Chromosome variation in taro, Colocasia esculenta: Implications for origin in the Pacific. Cytologia 53:551-560.

10. Croat, T. B. 1981. A revision of Syngonium (Araceae). Ann. Mo. Bot. Gard. 68:565-651.

11. Davis, L. H. 1953. Black cane rot of Syngonium auritum. (Abstr.) Phytopathology 43:586.

12. DeScenzo, R. A., and Harrington, T. C. 1994. Use of $(\mathrm{CAT})_{5}$ as a DNA fingerprinting probe for fungi. Phytopathology 84:534-540.

13. Engelbrecht, C. J. B., and Harrington, T. C. Intersterility, morphology, and taxonomy of Ceratocystis fimbriata on sweet potato, cacao, and sycamore. Mycologia (In Press).

14. Engelbrecht, C. J. B., Harrington, T. C., Steimel, J., and Capretti, P. 2004. Genetic variation in eastern North American and putatively introduced populations of Ceratocystis platani. Mol. Ecol. 13:2995-3005.

15. Food and Agriculture Organization. 2002. FAOSTAT statistics database. Published online by Food and Agriculture Organization of the United Nations (FAOSTAT)

16. Giacometti, D. C., and León, J. 1994. Tannia, yautia (Xanthosoma sagittifolium). Pages 253-258 in: Neglected Crops: 1492 from a Different Perspective. J. E. Hernández-Bermejo and J. León, eds. FAO Plant Production and Protection Series, Rome.

17. Harrington, T. C. 2000. Host specialization and speciation in the American wilt pathogen Ceratocystis fimbriata. Fitopatol. Bras. 25:262263.

18. Harrington, T. C., McNew, D., Steimel, J., Hofstra, D., and Farrell, R. 2001. Phylogeny and taxonomy of the Ophiostoma piceae complex and the Dutch elm disease fungi. Mycologia 93:111-136.

19. Harrington, T. C., and Rizzo, D. M. 1999. Defining species in the fungi. Pages 43-71 in: Structure and Dynamics of Fungal Populations. J. J. Worrall, ed. Kluwer Academic, Dordrecht, the Netherlands.

20. Harrington, T. C., Thorpe, D. J., Marinho, V. L. A., and Furtado, E. L. First report of black rot of inhame (Colocasia esculenta) caused by Ceratocystis fimbriata in Brazil. Fitopatol. Bras. (In Press).

21. Hinds, T. E. 1972. Insect transmission of Ceratocystis species associated with aspen cankers. Phytopathology 62:221-225.

22. Iton, E. F. 1960. Studies on a wilt disease of cacao at River Estate. II Some aspects of wind transmission. Pages 47-58 in: Annual Report on Cacao Research, 1959-1960. Imperial College of Tropical Agriculture, University of the West Indies, St. Augustine, Trinidad.

23. Johnson, J. A., Baker, C. J., Harrington, T. C., and Nason, J. D. 2002. Allozyme and DNA sequence analysis of Ceratocystis fimbriata isolates reveal geographic groupings and host associated lineages. (Abstr.) Phytopathology 92(suppl.):S40.

24. Kawakita, K., and Kojima, M. 1983. The isolation and properties of a factor of taro tuber that agglutinates spores of Ceratocystis fimbriata, black rot fungus. Plant Cell Physiol. 24:41-49.

25. Kojima, M. K., and Uritani, I. 1974. The possible involvements of a spore-agglutinating factor(s) in various plants in establishing host specificity by various strains of black rot fungus. Plant Cell Physiol. 15:733-737.

26. Marin, M., Castro, B., Gaitan, A., Preisig, O., Wingfield, B. D., and Wingfield, M. J. 2003. Relationships of Ceratocystis fimbriata isolates from Colombian coffee-growing regions based on molecular data and pathogenicity. J. Phytopathol. 151:395-405.

27. Masui, H., Kondo, T., and Kojima, M. 1989. An antifungal compound, 9,12,13-trihydroxy-(E)-10-octadecenoic acid, from Colocasia antiquorum inoculated with Ceratocystis fimbriata. Phytochemistry 28:2613-2615.

28. Matthews, P. J. 1995. Aroids and the Austronesians. Tropics 4:105-126.

29. Mizukami, T. 1950. Comparison of the pathogenicity of Ceratostomella fimbriata and Endoconidiophora sp. causal fungus of taro black-rot, on sweet potatoes and taroes. Sci. Bull. Fac. Agric. Kyushu Univ. 12:5-9.

30. Moller, W. J., and DeVay, J. E. 1968. Carrot as a species-selective medium for Ceratocystis fimbriata. Phytopathology 58:123-124.

31. Moller, W. J., and DeVay, J. E. 1968. Insect transmission of Ceratocystis fimbriata in deciduous fruit orchards. Phytopathology 58:1499-1508.

32. Pasura, A., and Harrington, T. C. 2004. Two undescribed species in the Ceratocystis fimbriata complex on Ficus and Colocasia from Asia and Polynesia. (Abstr.) Phytopathology 94(suppl.):S160-S161.

33. Shimizu, M. 1939. Black rot of dasheen. Pusan Customs, Plant Inspection Rep. No. 1., Japan.

34. Steimel, J., Engelbrecht, C. J. B., and Harrington, T. C. 2004. Development and characterization of microsatellite markers for the fungus Ceratocystis fimbriata. Mol. Ecol. Notes 4:215-218. 
35. Swofford, D. L. 2002. PAUP: Phylogenetic Analysis Using Parsimony (and Other Methods). Version 4.0b10a. Sinauer Associates, Sunderland, MA.

36. Thorpe, D. J. 2004. Phylogenetics, intersterility and host specialization of Ceratocystis fimbriata from Brazil and the family Araceae. M.S. thesis. Iowa State University, Ames.

37. Triana, E. L. M., and Diaz, C. A. 1989. Ceratocystis fimbriata, causante de la pudricion negra de la malanga. Cienc. Tecnol. Agric. Viandas Tropicales 12:21-28.

38. Uchida, J. Y., and Aragaki, M. 1979. Ceratocystis blight of Syngonium podophyllum. Plant Dis. Rep. 63:1053-1056.
39. Vogelzang, B. K., and Scott, E. S. 1990. Ceratocystis fimbriata, causal agent of basal rot of Syngonium cultivars, and host range studies of isolates of C. fimbriata in Australia. Aust. Plant Pathol. 19:82-89.

40. Walker, J., Tesoriero, L., Pascoe, I., and Forsberg, L. I. 1988. Basal rot of Syngonium cultivars and the first record of Ceratocystis fimbriata from Australia. Aust. Plant Pathol. 17:22-23.

41. Webster, R. K., and Butler, E. E. 1967. A morphological and biological concept of the species Ceratocystis fimbriata. Can. J. Bot. 45:1457-1468.

42. Wingfield, M. J., DeBeer, C., Visser, C., and Wingfield, B. D. 1996. A new Ceratocystis species defined using morphological and ribosomal DNA sequence comparisons. Syst. Appl. Microbiol. 19:191-202. 